\title{
Intensive ESL Programmes in Quebec Primary Schools ${ }^{1}$
}

Nina Spada and Patsy M. Lightbown

This paper is a report on a study designed to investigate the second language development of francophone children in experimental intensive ESL programmes in Quebec primary schools. Classroom interaction patterns and learners' contact with and attitudes toward English were also investigated. Learners in the intensive programmes were compared with learners in regular ESL programmes at the same grade level, as well as with learners who had received a comparable number of hours of instruction spread over a longer period of time. The results indicated that the intensive programme learners outperformed both comparison groups on tests of listening and reading comprehension and in oral fluency. In addition, although both regular and intensive programme learners were found to have very little contact with English prior to instruction, the intensive programme learners indicated somewhat greater contact after instruction. They also held more positive attitudes toward English than did the regular programme learners.

Something unexpected is happening in the English second language (ESL) programmes in a growing number of Quebec's French-language primary schools. Instead of providing students with the regular programme of 120 minutes of ESL instruction per week in grades 4,5 and 6, some school boards are offering five hours of instruction per day for five months of one school year. ${ }^{2}$ The increased availability of these intensive courses is the result of pressure by francophone parents on the school boards to provide more opportunities for their children to develop greater English language proficiency. Indeed, this pressure for educational innovation in ESL is not unlike the pressure put on English language school boards about twenty-five years ago by anglophone parents who wanted their children to develop greater French second language (FSL) abilities. This eventually led to the creation of French immersion programmes (Lambert and Tucker, 1972) which are now offered in schools across Canada. These programmes are widely acknowledged to be the most successful way of developing second language proficiency ever implemented in broad-based educational programmes in contexts where the second language is not spoken in the child's immediate environment (See Bibeau, 1983; Genesee, 1987; Swain and Lapkin, 1981 for perspectives on the strengths and weaknesses of French immersion programmes.)

Quebec's experimental intensive ESL programmes are different from 
French immersion programmes: while it is possible under the current language laws in Quebec to provide subject-matter instruction in French in English-medium schools (in French immersion or "extended French" programmes), subject-matter instruction in English in French-medium schools is not permitted. The policies of the Government of Quebec require that, except for the direct teaching of ESL as one school subject, all subject matter instruction and evaluation of student performance in Frenchmedium schools must be offered in French. Thus, the language-throughsubject-matter approach of the immersion programmes is not available in the intensive ESL classes. Instead, students receive instruction in the English language through topics and themes which are not part of the regular subject-matter curriculum during one half of the school year and take their regular subjects in French during the other half.

This paper is a report on a three-year research project designed to investigate various aspects of the teaching practices and learning outcomes in some of the experimental intensive programmes. Before describing the research design and methodology of the study, it is important to provide a general description of ESL instruction within the province of Quebec along with a brief history of the intensive programmes.

\section{ESL Instruction in Quebec}

The Ministry of Education of Quebec (MEQ) recommends that ESL instruction begin in grade 4 (at 9 years of age for most pupils) and be given for 120 minutes per week in grades 4,5 and 6 and 150 minutes per week in each of the five years of secondary school. In school boards which conform to this recommended timetable, students receive less than 700 hours of ESL instruction spread over eight years. This may be contrasted with approximately 1000 hours of exposure to French which Englishspeaking students get in one year of French immersion. ${ }^{3}$ A recent survey carried out by the MEQ in preparation for an evaluation of its new curriculum showed that less than $25 \%$ of elementary schools sampled offer as much as 120 minutes per week.

This limitation on the amount of time available for instruction ensures that few students will achieve more than minimal skills in English. While there is no magic number of hours required for achieving functional bilingualism, some experts have argued that this "drip-feed" approach is the worst possible way to organize language instruction (Hawkins, 1978, 1988; Stern, 1985; Swain, 1981). In his discussion of the weaknesses inherent in a drip-feed approach, Diller (1978, p. 136) quotes Gouin $(1880$, p. 298) as saying that "whoever does not in the space of the four seasons of one year manage to learn practically all there is to be learned of the basis of a language will never learn it." 
In the late 1970's, some Quebec schools developed experimental programmes of intensified instruction in ESL. These experimental programmes were based on dissatisfaction with ESL achievement, some parental demands for an English immersion programme comparable to what was available to anglophone children in French immersion, andquite significantly-on the observation that immigrant children could learn enough French in one school year of intensive instruction in classes $d^{\prime} a c$ cueil (welcoming classes) to permit them to be mainstreamed in the regular classes of a French-medium school. Some observers of this phenomenon concluded that a relatively short period of intensive language instruction was more effective than either the drip-feed approach or French immersion. Indeed the stronger claim was made that five months of intensive instruction would result in better language performance than would five years of attendance at a school where the second language was the medium of instruction (Billy, 1980). It is important to emphasize that the research on which this conclusion was based was incomplete (Lightbown, 1987).

Until the mid-1980's, intensive ESL programmes existed in only a very small number of schools in Quebec. Recently, interest in these programmes has increased and the number of schools and school boards offering them is rising rapidly (Lightbown, Conan, Bolduc and Guay, 1988). Although parents, teachers and students informally express a high degree of satisfaction with this approach, extensive and systematic evaluative research is needed before a wide-scale implementation of such programmes should be considered. ${ }^{4}$

We have been involved in the on-going evaluation of learner language in these programmes since 1984-85. In the 1984-85 and 1985-86 school years, the study was limited to pilot testing in a small number of classes. In the 1986-87 year, we began a larger study, first in four schools (see Lightbown and Spada, 1987) and, in the 1987-88 school year, the research expanded to include a total of 10 schools. This longitudinal study has been designed to investigate both the second language development of children and the characteristics of classroom instruction in these intensive programmes. Learner language has been examined through a pre/post-test design to investigate listening and reading comprehension as well as through a descriptive analysis of learners' oral performance. Classroom interaction has been investigated through structured observations of classrooms, analysis of teaching materials and interviews with teachers. In addition, learner variables such as contact with English outside school and attitudes toward learning English have been examined on a pre/postinstructional basis.

So far, we have collected data from approximately 1000 students in 41 classes at the grade 5 and 6 levels. We have completed the analyses of learners' performance on the pre/post-test listening and reading com- 
prehension measures for the 1986-87 and 1987-88 cohorts-over 800 students in 33 classes. In addition, the pre/post-test performance of over 200 grade 5 and 6 students in regular ESL programmes has been assessed. As well, the questionnaires to measure learners' contact with and attitudes toward English have been analyzed. We have also completed some of the classroom interaction analyses for 20 classes. The analyses of learner performance in terms of their oral productive skills is in progress as we continue to explore several different approaches in our description of the language of these learners in both linguistic and communicative terms.

Below, a description of the subjects in the study is provided along with a description of the measurement instruments used to collect data on learner language, learner attitudes and contact with English, and classroom interaction in the intensive classes. This is followed by a presentation and discussion of the results of the analyses completed so far.

\section{Subjects}

Thirty-three groups of students (intact classes of 26-30 students each) make up the intensive programme subjects of this study. Nineteen groups of grade 5 students and 14 groups of grade 6 students were included. The students are native speakers of French, and as a rule, they were admitted to these classes if they were considered to be "unilingual", that is, having little knowledge of English apart from what they had learned at school in the very few hours of regular ESL instruction they had received. Students who had developed some fluency with English outside of the school context or who could be considered bilinguals were not ordinarily permitted access to the intensive classes. ${ }^{5}$ It was often the case that there were many more students who wished to participate in the programme than there were spaces available. Some schools dealt with this by simply drawing at random the names of the required number of eligible volunteers. Others used a stratified sample approach, selecting students from different academic ability levels in proportion to their representation in the grade level.

Students in the intensive programme received a total of approximately 350-400 hours of ESL instruction in full-day programmes where, for five months, English was taught during all school hours except those in which French was used by school specialists to teach art, physical education, music and religion. The 33 intensive classes were drawn from eight school boards. Each school board has developed and implemented its programme independently although some of them use the same pedagogic materials. As a result, while there has been some limited consultation, there has been little ongoing contact between programme administrators and teachers in these separate experimental intensive programmes regarding student selection, materials development, methodological procedures, teacher training 
and programme evaluation. There has been even less contact about the day-to-day activities of the classes.

On pre- and post-test measures, we examined the performance of comparison groups (grade 5 and grade 6 learners who were in the regular ESL programmes). For some aspects of oral performance, we were able to compare the English of a group of grade 10 students who, at the time of testing, had accumulated approximately the same number of hours of instruction as the intensive programme subjects. On one of the post-test measures, it was also possible to compare intensive programme learners to grade 9 students throughout the province of Quebec. This will be detailed below.

It is important to acknowledge from the outset some problems with finding appropriate comparison groups. In addition to the differences of age (grade 9 and 10 groups) and total hours of ESL instruction (grade 5 and 6 comparison groups), these two types of comparison groups differ from each other in another important way. The grade 9 and 10 students had received their English instruction in the "old" MEQ programme, a modified audiolingual approach with a strong emphasis on rote learning and the accurate reproduction of complete sentences. The grade 5 and 6 students (both intensive and comparison groups), on the other hand, had been exposed to ESL under the "new" programme which has a strong communicative orientation, that is, one in which the emphasis is on meaningful interaction and little attention is paid to accuracy in syntax or morphology. Because this instructional orientation was introduced in Quebec schools only within the past five or six years, it is only now becoming possible to locate comparison groups who have accumulated the same total number of hours of instruction as the intensive programme students under the same communicative programme.

\section{Measurement Instruments: Classroom Interaction}

Current research in classroom learning has emphasized the importance of knowing what actually happens during the instructional process (classroom interaction) as well as describing the instructional product (learner performance) (Long, 1980). In order to describe with some accuracy the characteristics of classroom instruction in these programmes, we included a classroom observation component as well as interviews and questionnaires for the intensive programme teachers. A modified version of the COLT (Communicative Orientation of Language Teaching) Observation scheme was used to describe teacher and learner behaviours in both pedagogic and linguistic terms. The scheme measures such features as the amount of time spent in teacher-centred or group-centred activities, the extent to which teachers focus on language itself or meaning, the oppor- 
tunities for learners to produce minimal or sustained speech, the relative frequency of "display" and "referential" questions on the part of the teacher, etc. (See Allen, Fröhlich and Spada, 1984; Fröhlich, Spada and Allen, 1985; Spada, 1987, in press, a, for descriptions of the scheme and its use in studies of different L2 programmes).

A total of 64 classroom observation visits were made for the 1986-87 and 1987-88 cohorts. These were whole-day visits which took place at intervals over the five months of instruction. During these visits one observer sat in the classroom and coded for specific features on the COLT scheme. At the same time, classroom events were audio-recorded for further analysis. One microphone was placed on the teacher's desk to record verbal interaction going on in the whole class. In addition, teachers wore a small tape recorder around their necks to pick up all teacher-talk, as well as any interaction they had with individual students or groups of students.

\section{Measurement Instruments: Learners' Background, Attitudes and Contact with English}

A questionnaire was administered to probe the students' contact with and attitudes toward English before and after instruction. It was administered in French at the beginning of the period of instruction and an adapted version was administered at the end of the instruction (See Appendix I). In the case of the grade 5 and 6 comparison groups, the questionnaire was administered at the beginning and end of the school year. The questionnaire was designed to determine the language spoken at home (BACKGROUND), the amount of out-of-classroom contact with English the subjects had before and during their intensive instruction (CONTACT), and learners' motivation and attitudes toward English (ATTITUDES).

\section{Measurement Instruments: Learner Language}

One test has been used to directly measure the subjects' performance on a pre/post-test basis. The Baldwin-Cartier Test de classement (BCT) was developed by a school board in the Montreal area for use in streaming its students into three different types of English programmes offered by the board: ESL for beginners, ESL for intermediates, and advanced courses for students with native or near-native ability in English. Pilot testing had indicated that the grade 3 version of this test was the most suitable one to use with our subjects. ${ }^{6}$

At the end of the five month programme, two additional measures were used. The first test had been developed by the MEQ to measure the English listening comprehension of grade 9 students. This test aims to measure learners' knowledge of English acquired both in the school setting and 
through informal contact with English speakers or English media. As the MEQ had administered this test to nearly 27,000 grade 9 students across the province in 1981, we were able to use this measure to investigate how learners in the intensive programmes compared with a very large number of learners who had received approximately the same total number of hours (400-500), spread over a much longer period of time (5-6 years), in regular ESL programmes, as well as to the comparison groups of grade 5 and 6 students in our own study. (See Appendix II for examples of the type of items in the BCT and MEQ tests).

Finally, we used an oral communication task referred to as the Picture Card Game (PCG). The purpose of this measure is to elicit a sample of natural language which can then be analyzed in a variety of ways-accuracy, fluency, etc. In order to play this game, the subject has to describe a picture so that the interviewer can guess from a set of four similar, but not identical pictures, which one the student is describing. (See Lightbown and Spada, 1978, 1987 for a more complete description of the PCG).

\section{Results: Classroom Interaction}

Since the analysis of the classroom observation data is preliminary, only a brief overview of the results obtained so far will be described here (See Spada, in press, b; Spada and Beaumont, 1988 for more detailed descriptions of the observation data).

A general description of the intensive classes is that they all represent instruction which is based on the current MEQ communicative approach to language teaching. Most teachers emphasize oral (listening and speaking) activities, in some cases to the virtual exclusion of reading and writing activities. The majority of classes focus primarily on meaning-based practice, a variety of participant interaction modes, integrated skills-based practice, and the use of a variety of written and visual materials. However, there are differences in the degree to which individual classes can be characterized in this way. For example, some teachers deal with grammar and accuracy more than others. In some cases there is instruction in vocabulary or grammar within the context of a communicative activity. In other cases, the code-related instruction is more isolated and decontextualized. As well, some instructors are more teacher-centred than others, thus providing learners with considerably more opportunities for listening to the teacher and fewer opportunities to speak and listen to each other in group work practice.

In addition to the differences which exist between individual classes and teachers, there are also within-class differences from one observation to the next. That is, the same teacher is more (or less) teacher-centred, or more (or less) meaning-based on one day than on another. Possible 
relationships between differences in individual classroom instruction and learning outcomes are being examined in ongoing research.

\section{Results: Learners' Background, Attitudes and Contact with English}

The pre-instruction questionnaire confirmed that virtually all learners in the study-both regular and intensive-were from strictly francophone families. Table 1 shows that, out of a possible 10 points on questions related to family language, the mean for the students was .43 (regular) and .28 (intensive). The significant difference between the two groups shows that the students from the regular programme are more likely to come from backgrounds where some English is spoken. Nevertheless, the overall picture is of almost uniformly francophone backgrounds.

Table 1

ANOVA Results for Pre-Instruction Questionnaire:

Language Background

$\begin{array}{lcccc} & \mathrm{N} & \mathrm{X} & \mathrm{sd} & \mathrm{F} \\ \text { Regular (Grade 5 \& 6) } & 211 & .43 & 1.02 & \\ \text { Intensive (Grade 5 \& 6) } & 834 & .28 & .64 & 13.56^{*} \\ { }^{*} \mathrm{p}=.0002 & & & & \end{array}$

The pre-instruction questionnaire on learners' contact with English outside the classroom allowed for a potential score ranging up to 11 . Table 2 shows that there was a difference between regular and intensive programme students. A greater degree of difference was observed between grade 5 and grade 6 students within the intensive programme. Nevertheless, the mean scores show that the students in both programmes have very limited contact with English-usually a few favourite television pro-

Table 2

ANOVA Results for Pre-Instruction Questionnaire:

Contact by Programme and Grade

$\begin{array}{lcccc} & \mathrm{N} & \mathrm{X} & \text { sd } & \mathrm{F} \\ \text { Regular (Grade 5 \& 6) } & 211 & 1.70 & 1.99 & \\ & & & & 6.28^{*} \\ \quad \begin{array}{l}\text { Intensive (Grade 5 \& 6) } \\ \quad \text { Grade 5 }\end{array} & 834 & 2.12 & 2.17 & \\ \quad \text { Grade 6 } & & 1.73 & 1.94 & 21.91 * * \\ { }^{*} \mathrm{p}=.0123 & 380 & 2.57 & 2.34 & \\ * \mathrm{*} p .0001 & & & & \end{array}$


grammes or a summer vacation in the U.S. or English-speaking areas of Canada. There was no evidence that students have significant exposure to written English.

Attitudes which students held toward English and the value of learning it are reflected in Table 3. The range of scores was from -3 to +5 . Both regular and intensive programme students have somewhat positive attitudes, but there is a significant difference between the regular and

Table 3

ANOVA Results for Pre-Instruction Questionnaire: Attitude by Programme and Grade

$\begin{array}{lcccc} & \mathrm{N} & \mathrm{X} & \mathrm{sd} & \mathrm{F} \\ \text { Regular (Grade 5 \& 6) } & 211 & 1.40 & 2.22 & \\ \quad & & & & 70.77^{*} \\ \quad \text { Intensive (Grade 5 \& 6) } & 834 & 2.51 & 1.56 & \\ \quad \text { Grade 5 } & 454 & 2.52 & 1.62 & .002 \\ \quad \text { Grade 6 } & 380 & 2.51 & 1.50 & \\ *_{p}<.0001 & & & & \end{array}$

intensive programmes. Students completed the questionnaire at the beginning of their grade 5 or grade 6 ESL instruction. At this point, it appears that those who knew they had been chosen for the intensive programme were more favorably disposed to the language than those who were in the regular programme. The virtual identity of the grade 5 and grade 6 intensive programme students tends to reinforce this impression.

Following the period of ESL instruction, both intensive and regular programme students reported more contact with English (see Table 4). The differences between the two are now dramatic, however. The considerably greater exposure to English is seen for both grade 5 and grade 6 intensive students with the greatest increase in contact shown by grade 5 .

Table 4

ANOVA Results for Post-Instruction Questionnaire:

Contact by Programme and Grade

$\begin{array}{lcccc} & \mathrm{N} & \mathrm{X} & \mathrm{sd} & \mathrm{F} \\ \text { Regular (Grade 5 \& 6) } & 211 & 2.22 & 2.63 & \\ & & & & 117.97^{*} \\ \text { Intensive (Grade 5 \& 6) } & 834 & 4.41 & 2.62 & \\ \quad \text { Grade 5 } & 454 & 4.32 & 2.60 & .02 \\ \quad \text { Grade 6 } & 380 & 4.53 & 2.51 & \\ \text { *p }<.0001 & & & & \\ \text { NINA SPADA AND PATSY M. LIGHTBOWN }\end{array}$


Intensive programme students' post-instruction attitudes are also more favourable than they were at the pre-instruction questionnaire, although the difference is slight (see Table 5). Attitudes of the regular programme students have declined slightly. Significant differences between regular

Table 5

ANOVA Results on Post-Instruction Questionnaire: Attitude by Programme and Grade

$\begin{array}{lcccc} & \mathrm{N} & \mathrm{X} & \mathrm{sd} & \mathrm{F} \\ \text { Regular (Grade 5 \& 6) } & 211 & 1.16 & 2.36 & \\ \quad \text { Intensive (Grade 5 \& 6) } & 834 & 2.71 & 1.30 & \\ \quad \text { Grade 5 } & 454 & 2.77 & 1.32 & \\ \quad \text { Grade 6 } & 380 & 2.63 & 1.27 & \\ \quad * \mathrm{p}<.0001 & & & & \end{array}$

and intensive programme students remain, as does the similarity between grade 5 and grade 6 intensive programme students.

\section{Results: Learner Language-Receptive Abilities}

Mean scores for intensive and regular programme classes on the pre-test listening comprehension measure (BCT) are presented in Table 6 . Although there are differences among individual classes within both the intensive and regular programme groups, an analysis of variance (ANOVA) indicated that there were no significant differences between the pre-test performance of students entering the intensive programme and those entering the regular grade 5 and 6 programme. As indicated in Table 6 , the group mean for the intensive programme learners was $29.67 \%$ and

Table 6

ANOVA Results for BCT Pre-test (20 item) by Programme and Grade

$\begin{array}{lcccc} & \mathrm{N} & \mathrm{X} & \mathrm{sd} & \mathrm{F} \\ \text { Regular (Grade 5 \& 6) } & 211 & 28.62 & 13.88 & \\ \begin{array}{l}\text { Intensive (Grade 5 \& 6) } \\ \quad \text { Grade 5 }\end{array} & 834 & 29.67 & 13.27 & 1.024 \\ \quad 454 & 28.06 & 13.53 & 14.88^{*} \\ \quad \text { Grade 6 } & 380 & 31.59 & 12.71 & \\ * \mathrm{p}<.0001 & & & \\ 20 & & & \\ & \text { TESL CANADA JOURNAL/REVUE TESL DU CANADA } \\ \text { VOL. 7, NO. 1, NOVMBER 1989. }\end{array}$


for the regular programme learners, $28.62 \%$. Within the intensive programme however, there were grade differences: the grade 6 mean score was significantly higher than the grade 5 score.

Table 7 presents the means for both intensive and regular programme classes on the BCT post-test. These results are based on an analysis of the

Table 7

ANOVA Results for BCT Post-test (20 item)

by Programme and Grade

$\begin{array}{lcccc} & \mathrm{N} & \mathrm{X} & \mathrm{sd} & \mathrm{F} \\ \text { Regular (Grade 5 \& 6) } & 183 & 38.63 & 19.36 & \\ \quad & & & & 367.90^{*} \\ \quad \text { Intensive (Grade 5 \& 6) } & 834 & 63.84 & 15.30 & \\ \quad \text { Grade 5 } & 454 & 63.12 & 15.40 & \\ \quad \text { Grade 6 } & 380 & 64.71 & 15.15 & .25 \\ * \mathrm{p}=.0001 & & & & \end{array}$

NOTE: One group of regular programme students was not available for this test.

same 20 items of the BCT which were used as the pre-test. It is clear that the two groups who were not significantly different from each other on the pre-test, are, on the post-test, dramatically different from each other. ${ }^{7}$ Within the intensive programme the grade differences observed on the pre-test are no longer present.

The MEQ test was used as a post-test only. Although the full 53-item MEQ test was administered to the intensive group, only 32 items were administered to the comparison group because it was felt that the 53-item test would be too difficult for them. Results from the 32-item test appear in Table $8 .^{8}$ An ANOVA of the 32-item test results indicated a significant difference between the intensive programme group and the regular programme group.

Table 8

ANOVA Results for MEQ Post-test (32 items)

by Programme and Grade

$\begin{array}{lcccc} & \mathrm{N} & \mathrm{X} & \mathrm{sd} & \mathrm{F} \\ \text { Regular (Grade 5 \& 6) } & 211 & 33.41 & 19.35 & \\ & & & & 475.78^{*} \\ \quad \text { Intensive (Grade 5 \& 6) } & 834 & 61.29 & 15.81 & \\ \quad \text { Grade 5 } & 454 & 58.70 & 15.16 & \\ \quad \text { Grade 6 } & 380 & 64.39 & 16.04 & \\ \text { * }<.0001 & & & & \end{array}$


The means for all intensive classes on the 53-item MEQ test were combined and compared with the results of a group of approximately 27,000 grade 9 students who took the MEQ test in 1981. The grand mean for all intensive students $(\mathrm{N}=834)$ was $59.48 \%$; for the grade 9 students, the mean score was $54.34 \%$. Mean scores for individual classes in the intensive programme ranged from $46.33 \%$ to $75.60 \%$ on this test.

To summarize the results of the analysis of intensive learners' listening and reading comprehension abilities, they significantly outperform the regular programme learners at the same grade level-a finding which is hardly surprising in light of the far greater number of hours of instruction. But they also tend to perform better than those who are at a higher grade level who have received a comparable number of hours of instruction.

As indicated earlier, the comparison between intensive and the grade 9 regular programme students is problematic because of differences in instructional methodology as well as age. The different results may be attributable to type of instruction as well as (or even instead of) differences in the intensity of instruction. This will be explored in our ongoing research when we compare intensive programme students to secondary students in programmes of communicative language teaching.

A number of correlational analyses were carried out to explore relationships between certain pre-instruction and post-instruction variables and the post-instruction performance of students in both regular and intensive classes. Some of these correlations are reported in Tables 9 and 10. Although, as would be predicted, there is a tendency for variables such as pre-test score, contact with English, and attitudes toward English to be positively correlated with post-test performance for both groups, the relationship of non-instructional variables is considerably stronger for the regular programme students. This suggests that the influence of instruction is greater and more evenly distributed in the intensive programme students. These relationships will be investigated more thoroughly in subsequent quantitative and qualitative analyses.

Table 9

Correlations between Pre-test and Questionnaire Variables and Post-test Results-Intensive Programme

$\begin{array}{lcc} & \text { BCT-POST } & \text { MEQ-POST } \\ \text { BCT - PRE } & .372 & .366 \\ \text { CONTACT - PRE } & .198 & .228 \\ \text { CONTACT - POST } & .180 & .159 \\ \text { ATTITUDE - PRE } & .252 & .204 \\ \text { ATTITUDE - POST } & .320 & .329\end{array}$

NOTE: All correlations were significant at $p<.0001$ 
Table 10

Correlations between Pre-test and Questionnaire Variables and Post-test Results-Regular Programme

$\begin{array}{lcc} & \text { BCT-POST } & \text { MEQ-POST } \\ \text { BCT - PRE } & .523 & .507 \\ \text { CONTACT - PRE } & .312 & .289 \\ \text { CONTACT - POST } & .456 & .312 \\ \text { ATTITUDE - PRE } & .229 & .312 \\ \text { ATTITUDE - POST } & .382 & .399\end{array}$

NOTE: All correlations were significant at $\mathrm{p}<.0001$

\section{Results: Learner Language-Oral Production}

All intensive programme learners in the 1986-87 cohort and a sample of comparison group learners were tape recorded as they played the Picture Card Game during the last week of their grade 5 or grade 6 ESL instruction. With the 1987-88 cohort, samples of both intensive and comparison programme learners were tape recorded. To date, most of these recordings have been transcribed for analysis. In this paper we will report on some aspects of the performance of 40 learners from the 1986-87 cohort (See Lightbown, in press; Lightbown and Spada, 1987, in preparation for more details of the analyses and an explanation of the sampling procedures used to select the forty subjects). Learners' performance on the PCG was analyzed in terms of some aspects of fluency, accuracy and linguistic complexity.

In terms of fluency, learners in the intensive programmes were found to be extremely talkative in describing the pictures in the PCG. Indeed it was often difficult to get them to stop! They produced on the average, about 300 words to describe two of the more complex pictures. This differs strikingly from the learners in the comparison classes (i.e. those in the regular grade 5 and 6 ESL programmes) who produced very little speech (approximately 50 words) to describe the same pictures and who required a great deal of prompting from the interviewer to do so. Not surprisingly, learners in the intensive classes also produced a greater variety of vocabulary items as well.

In terms of their accuracy in the use of two grammatical morphemes in obligatory contexts (viz the progressive -ing and the plural $-s$ ), intensive programme students were approximately $50 \%$ accurate in their use of plural $-s$ and less than $20 \%$ accurate in their use of the progressive -ing. Other grammatical morphemes such as markers of the 3rd person singular and possessive were omitted even more frequently. An analysis of the use of these morphemes and others is currently underway with the complete 
sample of learners from both the intensive and regular programme learners. $^{9}$

A syntactic word order analysis based on a framework of second language developmental stages proposed by Pienemann and Johnston (1986) was undertaken with the same 40 subjects. This revealed that in terms of the 5-stage framework of development, all subjects showed a predominant Stage 1 (simple SVO word order) pattern in their speech. There were few instances of other sentence types although most subjects produced at least one example of adverb fronting (e.g. At the front of the class, there is a teacher) which is considered to be at stage 2 on the Pienemann and Johnston developmental scale. There were no instances of more complex sentence structures.

To date, these analyses have been carried out only with the intensive programme learners. As indicated above, the oral ability of learners in the regular ESL programmes is quite limited in comparison and few students produce sufficient language for this type of analysis. As our research continues, we hope to make comparisons with older learners with comparable total instruction time. In the meantime, it is clear that most students in intensive programmes have developed fluency skills in English as well as confidence and ease in using their second language. Although they make numerous grammatical errors, one would not expect high levels of accuracy so early in their development. In any case, the focus of instruction was on communicating intentions and meanings, not on producing grammatically correct sentences and structures.

\section{Conclusions}

Intensive ESL courses are having a profound impact on Quebec schools. The demand for the programmes is growing very rapidly. Many new classes have begun and others will begin in the next school year. There is no doubt that the potential for learning ESL is dramatically better in these programmes than in the traditional drip-feed approach. Even so, we wish to include in this report a note of caution, pointing to a number of areas where important work remains to be done.

1) Long term effects: So far, no research has explored the extent to which learners maintain their post-intensive ability in English. Such follow-up studies need to determine whether learners are sufficiently advanced to continue learning on their own or whether they need special secondary ESL programmes targeted to their level of proficiency (rather than the mainstream courses now offered by most schools). Where special secondary programmes are in place, their effectiveness needs to be investigated.

2) Only a few local studies have measured learners' performance on 
grade 5 or 6 French and math skills which they do intensively in the other half of their intensive ESL year. Anecdotal evidence suggests that students consider the five months of intensive math and French stimulating and challenging, and that they do just as well in these subjects as those who studied them over ten months. Nevertheless, their long- and short-term success in these areas need to be documented.

3) The selection of students for these programmes is problematic in some school boards. Teachers of the classes made up of students who were not admitted to the intensive programmes have sometimes complained that students with learning or behaviour problems are over-represented in their classes. From an administrative point of view, such concerns are potentially very serious and must be dealt with if intensive programmes are to be acceptable in a larger number of schools. This is especially true where the implementation of intensive ESL classes causes significant disruption of some aspects of the school's routines.

4) Related to 3) above is the fact that, for the most part, participation in these programmes has so far been almost entirely on a voluntary basis. With their increased popularity, there may be a tendency in some areas to make them a part of every child's primary school programme. Such a move would be likely to change the outcomes considerably-not so much because students in the current groups are academically stronger or better language learners, but rather, because they consider themselves privileged and may tend to rise to the challenge with greater enthusiasm than if they were required to take the course. Generalization of the programme needs to be observed very carefully.

5) Most teachers involved in the programme so far are volunteers who have been willing to give more than the usual amount of time to their teaching responsibilities. They have had to create and adapt materials and develop evaluation materials because there is no official syllabus (beyond the regular MEQ syllabus for 120 minutes/week courses) and there are no published teaching materials available. The success of the programme has no doubt been attributable in part to these special teachers, aided quite often by a dedicated curriculum advisor. It is hard to predict the effect of imposing so demanding a teaching programme on an unwilling teacher.

Following these words of caution, we cannot refrain from expressing a subjective impression that these classes are among the most exciting and enjoyable we have ever seen. Teachers and students clearly feel that they are accomplishing a great deal and they are having fun at the same time. To have visited these classes in the first week and return four weeks later is to renew one's faith in the process of language learning in a classroom setting. However, intensive instruction is not a magic formula. Within the intensive programme, there is considerable variation, not only in the performance of individual learners but also from class to class. Over the next 
few years it will be essential to investigate in more detail the variables which contribute to these differences and to explore ways in which these innovative programmes can be made even more effective.

\section{NOTES}

1. The research reported here was funded by the Fonds pour la formation de chercheurs et l'aide à la recherche of the Quebec Ministry of Education and by the Social Sciences and Humanities Research Council of Canada. A number of the school boards also helped to defray the cost of the administration of tests. We thank the teachers and students who cooperated so fully and the wonderful research assistants who made it all possible. Randall Halter and Jack Upshur have, respectively, carried out and advised on statistical analysis.

2. Although there is considerable variety in the implementation of these ESL programmes, most schools provide students in intensive programmes with a minimal amount of English instruction before and after they attend the five-month intensive course.

3. French immersion programmes actually vary considerably in the number of hours of instruction given in French. Students in total immersion-where all instruction is in French-would receive 1000 hours in a year.

4. In spite of their popularity, there is opposition in principle to the intensive programmes on the part of some parents, teachers and school officials. In their opinion, Quebec's regulations concerning the distribution of time for each of the subject matters preclude the intensification of one subject matter and the concomitant reduction of time devoted to others. To date, the MEQ has not taken an official position on the legality of the programmes. It is to be hoped that this uncertainty will be resolved.

5. There were a few exceptions to this, and students with exceptionally high pre-test scores were not considered in the analysis of results.

6. Because this test was quite challenging for the learners, we used only 20 items of the 25 -item listening comprehension part of the test as our pre-test. After pilot testing, we chose not to use five of the listening comprehension items which were based on comprehension of an extended text. A 45-item version of the test (including the 20 items from the pre-test, plus 25 reading comprehension items) was used as the post-test. We thank the Baldwin-Cartier School Board for giving us permission to use this test.

7. In further contrast to the pre-test results, no significant differences were found between the performance of grade 5 and grade 6 intensive programme groups. The results of the 45 -item post-test are not presented. A correlation of the 20 -item and 45 -item test results revealed that the tests were providing virtually the same information $(r=.892, p<.0001)$.

8. For intensive programme students, results on the 32 and 53 -item test were highly correlated $(r=.912, p<.0001)$.

9. In a preliminary analysis and comparison of the oral performance ability of intensive programme learners with a group of grade 9 secondary learners whose ESL instruction had been in the audiolingual structural programmes, the secondary students were superior to the grade 5 and 6 intensive programme students on some accuracy measures but not as strong in terms of fluency and general communicative effectiveness (see Paris, 1987 for more details of this analysis).

10. Questions 1 to 5 and 7 and 8 appeared only on the pre-instruction questionnaire. Question 9 appeared only on the post-instruction questionnaire.

11. For the comparison classes, this question read "au cours d'anglais" rather than "au cours intensif d'anglais".

12. Text within parentheses is tape recorded and does not appear in student test booklets. 


\section{REFERENCES}

Allen, J.P.B., M. Fröhlich, and N. Spada. (1984). The communicative orientation of second language teaching: An observation scheme. In J. Handscombe, R. Orem and B. Taylor (Eds.), On TESOL '83, Washington, D.C.

Bibeau, G. (1983). L'éducation bilingue en Amérique du nord. Montréal, Guérin.

Billy, L. (1980). Expérimentation d'une nouvelle approche en immersion. Canadian Modern Language Review, 36, 422-433.

Diller, K. (1978). The language teaching controversy. Rowley, Mass.: Newbury House.

Fröhlich, M., N. Spada, and J.P.B. Allen. (1985). Differences in the communicative orientation of L2 classrooms. TESOL Quarterly, 19, (1), 27-57.

Genesee, F. (1987). Learning through two languages. Cambridge, Mass.: Newbury House.

Gouin, F. (1892). The art of teaching and studying languages. (H. Swan \& V. Betis, Trans.). London: G. Phillip. (Original work published 1880).

Hawkins, E. (1978). Intensive teaching of foreign languages. In E. Hawkins and G.E. Perren (Eds.), Intensive language teaching in schools. London: Centre for Information on Language Teaching and Research.

Hawkins, E. (1988). Intensive language teaching and learning: Initiatives at the school level. London: Centre for Information on Language Teaching Research.

Lambert, W.E. and G.R. Tucker, (1972). Bilingual education of children. Rowley, MA: Newbury.

Lightbown, P.M. (In press). What have we here? Some observations of the influence of instruction on L2 learning. To appear in R. Phillipson, E. Kellerman, L. Selinker, M. Sharwood Smith and M. Swain (Eds.), Foreign language pedagogy research: A commemorative volume for Claus Faerch. Clevedon: Multilingual Matters.

Lightbown, P.M. (1987). L'enseignement de l'anglais langue seconde au Québec: bilan et prospective. Paper presented at the Premier congrès des sciences de l'éducation de langue française du Canada. Québec.

Lightbown, P.M. and N. Spada. (In preparation). Learners' developing L2 abilities in intensive, communicative programs. Montreal: Concordia University.

Lightbown, P.M. and N. Spada. (1987). Learning English in intensive programs in Quebec schools: 1986-87. Report on the first year of research. Montreal, Concordia University.

Lightbown, P.M. and N. Spada. (1978). Performance on an oral communication task by francophone ESL learners. SPEAQ, 2(1), 35-54.

Lightbown, P.M., H. Conan, I. Bolduc, and S. Guay. (1988). L'enseignement 
accru de l'anglais, langue seconde, dans les écoles primaire de langue française du Québec. Rapport de la Société pour la promotion de l'enseignement de l'anglais, langue seconde au Québec.

Long, M. (1980). Inside the "black box": Methodological isues in classroom research on language learning. Language Learning, 30, 1-42.

Paris, L. (1987). Some aspects of the second language development of children in intensive programs. M.A. thesis, Concordia University.

Pienemann, M. and M. Johnston. (1986). An acquisition-based procedure for second language assessment (ESL). Australian Review of Applied Linguistics, $9,(1), 92-122$.

Spada, N. (In press, a). Observing classroom behaviours and learning outcomes in different second language programs. To appear in J. Richards and D. Nunan (Eds.), Second language teacher education: Content and process. Cambridge University Press.

Spada, N. (In press, b). A look at the research process in classroom observation: A case study. To appear in C. Brumfit and R. Mitchell (Eds.), ELT Documents: Special Issue on Classroom Centred Research.

Spada, N. (1987). Relationships between instructional differences and learning outcomes: A process-product study of communicative language teaching. Applied Linguistics, 8, (2), 137-161.

Spada, N. and K. Beaumont. (1988). A look at some aspects of the classroom interaction in intensive ESL programs. Paper presented at the 1988 TESL Canada Summer Forum, Montreal, July, 1988.

Stern, H.H. (1985). The time factor and compact course development. TESL Canada Journal. 3(1), 13-27.

Swain, M. (1981). Time and timing in bilingual education. Language Learning. $31,1-15$.

Swain, M. and S. Lapkin. (1981). Bilingual education in Ontario: A decade of research. Report to the Ministry of Education. 


\section{Appendix I \\ QUESTIONNAIRE ${ }^{10}$}

Pour les numéros 1 à 5 on te demande d'encercler la bonne réponse.

Exemple: Quelle est ton équipe de hockey préférée?
Canadien
le Nordique

$\mathrm{Si}$ la réponse que tu veux donner n'est pas inscrite, écris-la sur la ligne.

Exemple: De quelle couleur sont tes cheveux?

bruns blonds

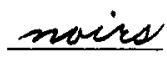

Lorsqu'une question ne te concerne pas, fais une croix $(X)$ sur la ligne.

Exemple: Quelle sorte d'auto possèdes-tu? européenne canadienne

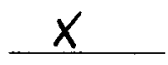

1. Quelle langue parles-tu d'habitude avec ta mère?

français anglais

2. Quelle est la langue maternelle de ta mère?

français anglais

3. Quelle langue parles-tu d'habitude avec ton père? français anglais

4. Quelle est la langue maternelle de ton père? français anglais

5. Quelle langue parles-tu d'habitude avec tes frères et soeurs? français anglais

Encercle la bonne réponse.

6. Est-ce qu'il t'arrive quelquefois de parler anglais avec les membres de ta famille?

jamais de temps en temps souvent tous les jours

7. As-tu déjà étudié dans une école anglaise?

oui non

8. Si tu as répondu oui au numéro 7 , réponds à ces questions aussi.

a) Où as-tu fréquenté une école anglaise?

b) Quel âge avais-tu lorsque tu as fréquenté une école anglaise?

9. Penses-tu que les heures que tu passes au cours intensif ${ }^{11}$ d'anglais sont trop nombreuses? trop peu nombreuses? exactement ce qu'il faut?

10. Penses-tu qu'il te faudra parler anglais au travail quand tu auras fini tes études? oui non Si oui, penses-tu que tu parleras anglais plus que français? moins que français? autant que français?

11. Est-ce que ton père ou ta mère parle anglais au travail? oui, mon père et ma mère oui, ma mère seulement non, ni mon père ni ma mère oui, mon père seulement

12. Est-ce qu'il y a quelqu'un avec qui tu parles anglais parce que cette personne ne parle pas français?

non oui, avec une personne oui, avec plusieurs personnes 
13. Penses-tu que tu seras capable un jour de bien parler anglais?

oui non

14. Par rapport à la majorité des étudiants dans ta classe, penses-tu que tu parles anglais

mieux?

aussi bien?

moins bien?

15. Par rapport à la majorité des étudiants dans ta classe, penses-tu que tu comprends l'anglais

mieux?

aussi bien?

moins bien?

Pour chacune des questions suivantes, on te demande de donner trois (3) réponses. Si tu ne peux pas fournir trois réponses à l'une ou l'autre des questions, donnes-en autant que tu peux et passe à la question suivante.

Exemple: Quels sont les légumes que tu aimes le plus?

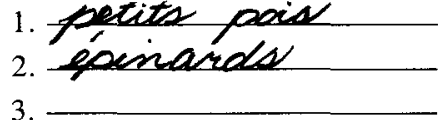

16. Est-ce que tu aimes regarder la télévision anglaise? Si oui, quelles sont tes émissions préférées?

1 .

2.

3.

17. Quels sont les trois derniers films en anglais que tu as vus au cinéma ou sur vidéo?

1.

2.

3.

18. Est-ce que tu aimes des chanteurs, des chanteuses, ou des groupes musicaux qui chantent en anglais? Si oui, peux-tu les nommer?

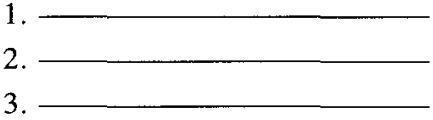

\section{TOURNE LA PAGE ET CONTINUE}

19. Les questions suivantes concernent le contact que tu as avec l'anglais en dehors de tes cours. Par une croix $(X)$ indique le nombre de fois que tu as rencontré l'anglais dans les situations suivantes. 


\begin{tabular}{|c|c|c|c|c|c|}
\hline Combien de fois as-tu & Jamais & $\begin{array}{c}\text { Presque } \\
\text { jamais }\end{array}$ & $\begin{array}{l}\text { Quelque- } \\
\text { fois }\end{array}$ & Souvent & $\begin{array}{c}\text { Tous les } \\
\text { jours }\end{array}$ \\
\hline \multicolumn{6}{|l|}{$\begin{array}{l}\text { a. parlé anglais avec des } \\
\text { amis francophones? }\end{array}$} \\
\hline \multicolumn{6}{|l|}{$\begin{array}{l}\text { b. parlé anglais avec des } \\
\text { amis anglophones }\end{array}$} \\
\hline \multicolumn{6}{|l|}{$\begin{array}{l}\text { c. parlé avec des adultes } \\
\text { anglophones? }\end{array}$} \\
\hline \multicolumn{6}{|l|}{$\begin{array}{l}\text { d. écouté la musique en } \\
\text { anglais? }\end{array}$} \\
\hline \multicolumn{6}{|l|}{$\begin{array}{l}\text { e. écouté l'anglais parlé } \\
\text { à la radio? }\end{array}$} \\
\hline \multicolumn{6}{|l|}{$\begin{array}{l}\text { f. regardé des émissions en } \\
\text { anglais à la télévision? }\end{array}$} \\
\hline \multicolumn{6}{|l|}{$\begin{array}{l}\text { g. été voir un film en } \\
\text { anglais au cinéma? }\end{array}$} \\
\hline \multicolumn{6}{|l|}{$\begin{array}{l}\text { h. lu un journal ou une } \\
\text { revue en anglais? }\end{array}$} \\
\hline \multicolumn{6}{|l|}{$\begin{array}{l}\text { i. lu des announces ou des } \\
\text { étiquettes en anglais? }\end{array}$} \\
\hline \multicolumn{6}{|l|}{ j. lu un livre en anglais? } \\
\hline $\begin{array}{l}\text { k. écrit une lettre en } \\
\text { anglais? }\end{array}$ & & & & & \\
\hline
\end{tabular}

\section{Appendix II}

\section{Examples of test items ${ }^{12}$}

I. Baldwin-Cartier Test de classement en anglais:

Pour chacun des numéros, dites quelle illustration convient le mieux à la phrase entendue.

1. (What's this? It's a cat.)
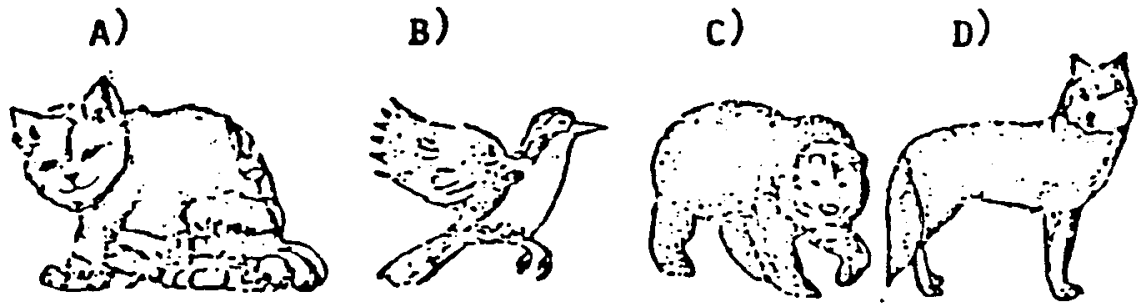
2. (What time is it, Mom? It's a quarter past one.)
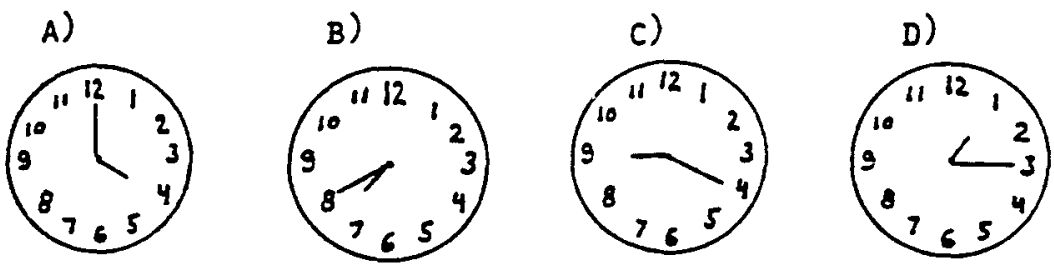

II. MEQ Test de compréhension de la langue orale: anglais langue seconde:

Indique quelle illustration convient le mieux à la phrase que tu auras entendue.

1. (This is a part of my body.)
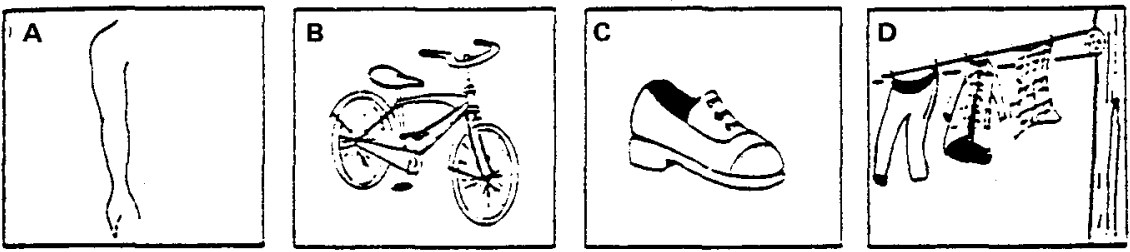

On te demande d'écouter le dialogue attentivement puis de répondre à la quesiton que tu trouveras dans ton cahier.

2. (-Hello, Mary. This is Jack. Is Paul at home?

-No, Jack. Paul and Tom've just left for the zoo.)

Question: Who is Mary talking to?
A) Jack.
B) Paul.
C) Tom.
D) Mary.

\section{THE AUTHORS}

Nina Spada is Assistant Professor and Graduate Programme Director in the Department of Education in Second Languages at McGill Univesity where she teaches graduate and undergraduate courses in second language acquisition, classroomcentred research and language teaching methods. Her research interests are in classroom interaction and second language learning in classroom settings. Her publications have included articles in Applied Linguistics, Studies in Second Language Acquisition, TESL Canada Journal and TESOL Quarterly.

Patsy M. Lightbown is Professor of Applied Linguistics in the TESL Centre at Concordia University where she teaches courses in first and second language acquisition. She is the convener for the Scientific Commission on Second Language Acquisition of the International Association of Applied Linguistics (AILA), and is a former Editor of the TESL Canada Journal (1984-1986). Her publications focus on classroom second language learning. In addition to her research in intensive programmes, she is currently engaged in a research project evaluating experimental ESL programmes in New Brunswick. 